\title{
Public procurement trends and developments in South Africa
}

Article $\cdot$ December 2016

DOI: 10.17261/Pressacademia.2016.351

CITATIONS

0

1 author:

ntaher Marcus Ambe

University of South Africa

23 PUBLICATIONS 75 CITATIONS

SEE PROFILE
READS

9

Some of the authors of this publication are also working on these related projects: 


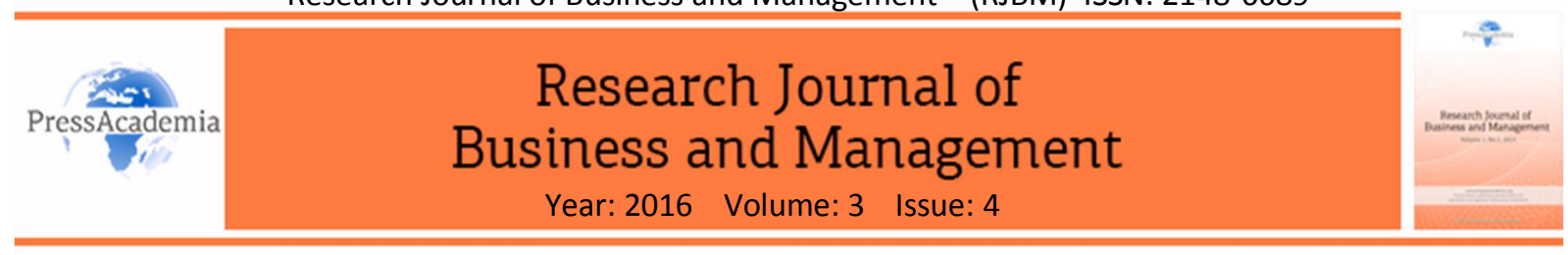

\title{
PUBLIC PROCUREMENT TRENDS AND DEVELOPMENTS IN SOUTH AFRICA
}

\author{
DOI: 10.17261/Pressacademia.2016.351
}

\section{Intaher Marcus Ambe}

University of South Africa. ambeim@unisa.ac.za

\begin{abstract}
Since the end of the apartheid regime in South Africa, public procurement has been used explicitly to pursue socio-economic objectives. Beyond the primary goal of advancing social objectives, public procurement in South Africa is also leveraged towards generating employment, enhancing domestic manufacturing capacity, and supporting the nascent renewable energy industry. This article explores public procurement practices in South Africa, and highlights the trends and developments that have emerged since 2004 based on a theoretical review. The article reveals that the lack of clearly defined strategic goals and various misconceptions about the concept of supply chain management, have led to the need for continuous transformation of procurement practices in the quest for better services to the citizens of the country. Some of the key public procurement trends and developments that have occurred since 2004 are discussed. This article recommends that, for South Africa government to gain the full benefit of procurement processes there is an urgent need for a shared vision among key stakeholders, ethical leadership and the development of sophisticated curricula by academic institutions.
\end{abstract}

Keywords: Public procurement, supply chain management, trends and developments, South Africa.

JEL Classification: M38

\section{INTRODUCTION}

Procurement is both a strategic tool and a mechanism enabling the South African government to implement policies for socio-economic development and transformation (Turley \& Perera, 2014). Public procurement operates in an environment of increasingly intense scrutiny and accelerated changes driven by technology, programme reviews, and political expectations (Bolton, 2006; Eyaa \& Oluka, 2011). It is a business process with an underlying political system (Wittig, 2007:2; Watermeyer, 2011:8). In South Africa, procurement is of particular significance in the public sector and is being used as a policy-making tool in view of the discriminatory and unfair practices of the past (Bolton, 2006:193). Procurement is central to the government's service delivery system and promotes aims which are, arguably, secondary to the primary aim of procurement, for example, using procurement to promote social, industrial or environmental policies (Cane, 2004). According to Bolton (2006:193), public procurement has been granted constitutional status in South Africa and is recognized as a means of addressing past discriminatory policies and practices.

Reforms in public procurement were initiated in 1995 to promote the principles of good governance and introduced a preferential system to address socio-economic objectives (Ambe, 2009). The reform process was initiated due to inconsistencies in policy application, lack of accountability, lack of supportive structures and fragmented processes. Mathee (2006:65) noted that a uniform implementation approach to procurement was required in view of the findings of a report on opportunities to reform procurement processes in the South African government. This report was the result of a 2001 study conducted by the Joint Country Assessment Review (CPAR) and the World Bank (National Treasury, 2003:2). The deficiencies and fragmentations in terms of governance, and the inconsistent interpretation and implementation of the Preferential Procurement Policy Framework Act 5 of 2000 (PPPFA), resulted in the introduction of supply chain management (SCM) in the public sector as a policy-implementation tool (National Treasury, 2005:8). This was the government's attempt to achieve the desired strategic policy outcomes through public procurement processes (McCrulden, 2004:257). 
Despite the reform processes in public procurement and the employment of SCM as a strategic tool, South Africa continues to face enormous challenges in its public procurement practices.

Public expenditure continues at high levels in the face of ever-increasing concerns about current procurement practices (SCM Review, 2015:4). There are constant allegations of corruption and inefficiencies in the procurement processes, and the significant number of service delivery protests in the country signals the prevailing dissatisfaction with basic services. According to Smart Procurement (Business Day, 2011), there is evidence of non-compliance with procurement legislation and policies, as well as of various tender irregularities. Accordingly, the Pretoria News (2011) asserted that 'taxpayers were fleeced of R30bn'. The article blamed this on corruption, incompetence and negligence by public servants. The Business Day report (2011) also affirmed that government had spent some R26.4-billion in 2010 in ways that contravened laws and regulations. The national and provincial governments and their entities notched up R21-billion in irregular expenditure in 2010, a 62\% rise over the R13-billion of previous year (Business Day, 2011). The journal stated that public procurement was in a state of "deterioration" which was extremely "disappointing", in view of the considerable efforts made by the government to curb malpractices. In his article, Munzhedzi (2016) equated procurement practices and corruption in the South African public sector as inseparable twins.

The SCM Review (2015) revealed that the implementation of consistent procurement practices across all spheres off government was all but satisfactory. Furthermore, practitioners responsible for the implementation of procurement policies are hindered by the lack of operational guidance on how to implement consistent procurement practices and how to put appropriate departmental policies into practice (Urría, 2016:4). It is a matter of concern that government is not making sufficient progress in implementing consistent procurement practices at the rate it would like to. In view of this state of affairs, the National Treasury has implemented numerous changes in an effort to improve public procurement practices to address the socio-economic issues of the country. It is within the context of these concerns and inadequacies that this article explores procurement practices in the South African public sector to determine current trends and developments.

Since procurement is a key tool and mechanism enabling government to implement policies for socio-economic development and transformation, it is important for the wider community to gain a better understanding of procurement practices. Earlier it was stated that procurement practices in the South African public sector would continue to evolve in the quest to provide better quality services and to the extent that government strives to address the socio-economic needs of the country. This article, which is based on a conceptual review of current practices and policies, begins by describing the state of public procurement practices in the country, and this is followed by a close scrutiny of existing procurement practices in the South African public sector. This is followed by a discussion of the trends and current developments in public procurement practices in South Africa.

\section{CURRENT STATE OF PUBLIC PROCUREMENT}

Government recognizes the potential of procurement to improve public sector productivity through savings and economies of scale (Gurría, 2016:3). According to Kashap (2004:133), it is an indispensable economic activity for good governance. Government agencies of independent nations, multilateral funding institutions and international aid organizations implement their development assistance and humane relief programs aimed at fighting diseases, reducing poverty and fostering economic and social development, through the national procurement processes.

The term "Public Procurement" refers to the purchase by governments and state-owned enterprises of goods, services and works. The public procurement process is the sequence of activities which start with the assessment of needs, and this is followed by the award of contracts, contract management processes, and finally payment $(O E C D, 2015)$. Reliable procurement practices will ensure that funds are used for, among others, the construction of hospitals, schools and roads. It is intended to benefit the general public and the goods and services so procured are generally provided through private enterprise. The government, the general public and private suppliers thus all have a direct interest in public procurement. Public procurement accounts for a substantial portion of taxpayers' money (approximately 12\% of GDP and $29 \%$ of government expenditure in OECD member countries). 
Since procurement accounts for such a large portion of public resources, it is important that the procurement process occurs in an accountable, transparent and well-managed manner to ensure high quality service delivery and safeguard the public interest (Heggstad, et al 2010:3; OECD, 2015). Therefore, public procurement remains the one government activity that is most vulnerable to waste, fraud and corruption due to the magnitude of the financial flows involved. Public procurement is used to achieve social policy objectives - that is, to foster job creation, to promote fair labour practices (such as the increased utilization of disabled citizens in employment), and as a means to prevent discrimination against minority groups (Uyarra \& Flanagan, 2009:2).

\section{PUBLIC PROCUREMENT PRACTICES IN SOUTH AFRICA}

\subsection{An Overview}

Since the end of the apartheid regime In South Africa, government procurement has been used explicitly to pursue socio-economic objectives (Turley and Perera, 2014). Procurement practices are of particular significance in the South African public sector. It is used to promote social, industrial or environmental aims which are, arguably, secondary to the primary aim of procurement (Bolton, 2009:10). This is due to the discriminatory and unfair practices of the past. The procurement transformation started in 1995 and was directed at two broad focus areas, namely the promotion of the principles of good governance and the introduction of a preferential system to address socio-economic objectives. The procurement reform processes were embedded in section 112 of the Municipal Financial Management Act 56 of 2003 (MFMA), in section 76(4) (C) of the Public Finance Management Act (PFMA), and in the Preferential Procurement Policy Framework Act 5 of 2000 (PPPFA). In 2001, the SCM unit at National Treasury completed a joint Country Procurement Assessment Review (CPAR) in collaboration with the World Bank to assess procurement practices throughout the public sector. The CPAR identified certain deficiencies in procurement practices relating to governance, and the interpretation and implementation of PPPFA and its associated regulations.

For example, it was found that the systems of procurement and provisioning were highly fragmented owing to the fact that tender boards were exclusively responsible for procurement while provisioning was largely underwritten by norms and standards within the logistics system driven by National Treasury. Effective and efficient financial management within government was continuously questioned. Moreover, a number of groups in South Africa were prevented from accessing government contracts. Prior to 1994, the government procurement system was geared towards large and established contractors. Thus, new contractors found it very difficult to participate in government procurement procedures. Moreover, the use of the logistics system as a tool for asset management also raised concerns regarding the improper handling of movable assets within the governmental environment. Since 1994, however, the South African government has made provision for the use of procurement as a means to address past imbalances. In addition, more emphasis was placed on integrated infrastructure development and the unlocking of government property to contribute to the optimization of resources. Over the past years, these concerns led the provincial treasuries, in conjunction with National Treasury, to embark on a vigorous reform initiative to introduce best procurement practices that are efficient and effective. To this end a new and strategically more powerful concept was pursued, namely, supply chain management.

\subsection{Supply Chain Management as a Procurement and Socio-Economic Tool}

In 2003 a SCM "policy to guide uniformity in procurement reform processes in government" in conjunction with provincial treasuries, was adopted in South Africa to replace the outdated procurement and provisional practices. This document, "Supply chain management: a guide for accounting officers (for national departments, municipalities and entities)", was developed to provide guidance on the adoption of the integrated SCM function and its related managerial responsibilities assigned to accounting officers in terms of sections 62 and 95 of the Municipal Finance Management Act (MFMA), and section 76 (4) of the Public Finance Management Act of 1999 (PFMA). These guides explain SCM regulations and policies through each step of the SCM cycle, as well as the operational processes for accounting officers. The principle behind the policy guide was based on the fact that managers should be given the flexibility to manage within a framework that satisfies the constitutional requirements of transparency and accountability. 
Prior to the introduction of the SCM policy, the focus of the South African government procurement process was on "meeting the requirements of the Tender Board". The Tender board was abolished, however, and institutions in government are now responsible for their own procurement processes, within the framework published by the South African National Treasury (2003). In most modern organizations, the function of asset management has also been changed to SCM. SCM is based on the same principles governing asset management, but recognizes that the effective and efficient functioning of the system could provide an area of competitive advantage and contribute, in the case of municipalities, to improved overall performance and promote service delivery and the ability to better service the needs of the community. Figure 1 illustrates the framework of the South African government's supply chain management process.

\section{Figure 1: South African Government Supply Chain Management Model}

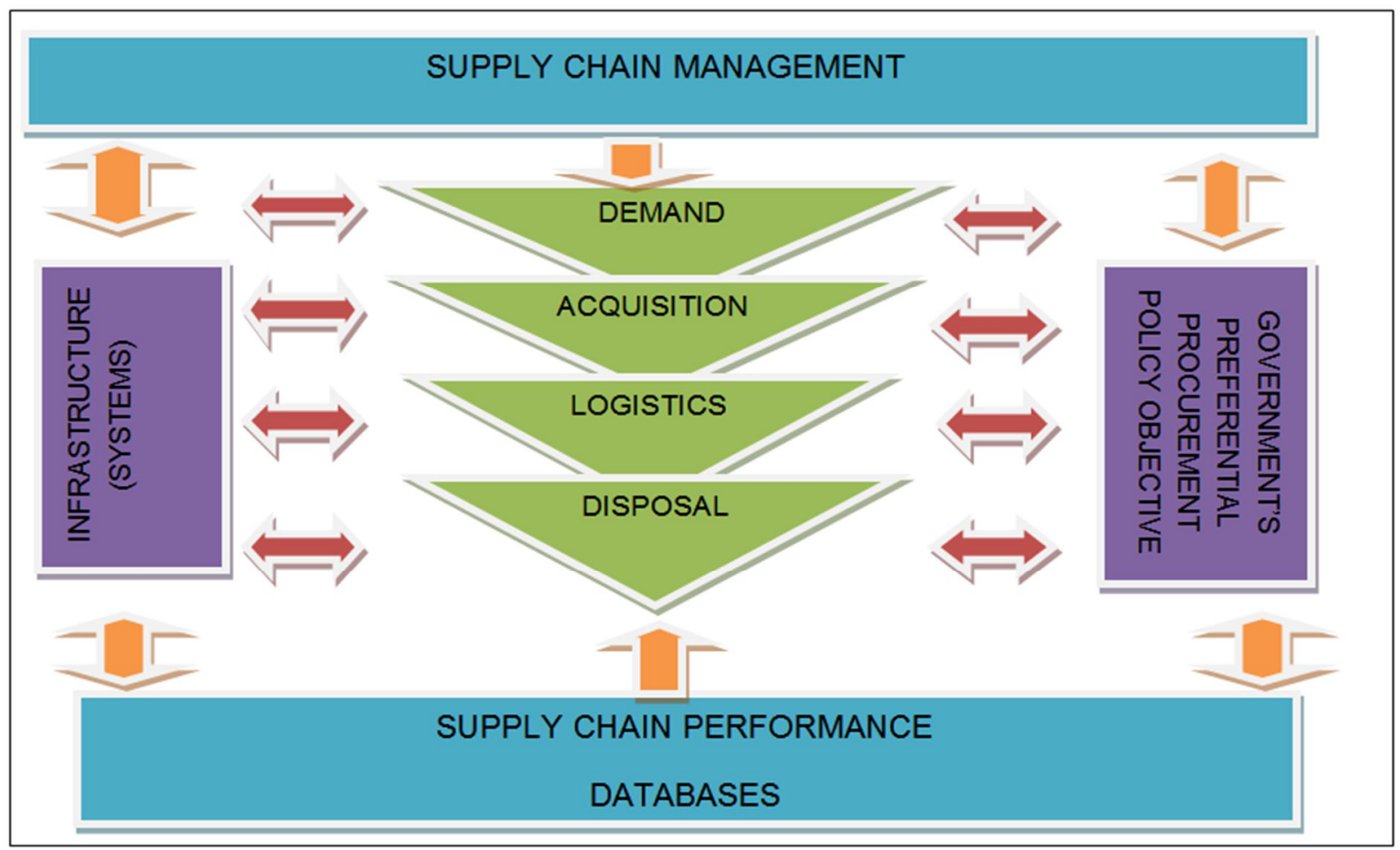

Source: National Treasury (2005).

The South African National Treasury provides guidelines for the implementation of the SCM policy. The framework for the SCM system constitutes demand management, acquisition management, logistics management, disposal management, and risk and performance management. The framework is guided by the preference points system aimed at achieving the re-distribution of wealth (by ensuring equal opportunities). The components of the supply chain process constitute the elements of the SCM systems. The supply chain process is built upon the principles of ensuring value for money, open and effective competition, ethics and fair practices, accountability and reporting, and equity. Ensuring these values will achieve the ultimate goal of uniformity in procurement processes, good governance and economic development (Mnguni, 2012; NT, 2005). With regard to SCM implementation, the Public Finance Management Act (1999) marks the transition to a decentralized procurement system, managed by Accounting Officers in national and provincial departments, and it also governs the timing and content of public budgets. The subsequent Municipal Financial Management Act (2003) establishes the regulatory framework for municipalities, namely the Supply Chain Management (SCM) process. 


\subsection{Public Procurement Governing Framework in South Africa}

Public procurement practices in South Africa are managed in accordance with the multifaceted SCM processes and activities of government. Prior to 1994, price was the overriding criterion for the procurement of goods and services by the government. Bolton (2009:11) indicates that even though price is still very important, it is no longer decisive. The 1996 Constitution makes express provision for the use of procurement as a policy tool. In February of 2000, effect was given to the relevant section of the Constitution with the promulgation of the Procurement Act. Section 217 of the Constitution of the Republic of South Africa, Act 108 of 1996, stipulates the primary and broad secondary procurement objectives, as indicated in Table 1 below. Section 217(3) of the Constitution requires that national legislation prescribes a framework within which the preferential procurement policy must be implemented. The PPPFA was promulgated in response to this constitutional imperative. Procurement by organs of state (National and Provincial Departments, Municipalities, Constitutional entities and public entities) is also governed by a number of other pieces of legislation.

As noted above, the public procurement processes and activities of the South African government are multifaceted. Numerous variables and a large body of information influence the SCM. Without a legislative framework, however, political representatives will not be able to make informed and intelligent decisions. Thus, in September 2003, the South African government adopted the "Policy to guide uniformity in procurement reform processes in Government." The policy strategy was to guide government's procurement reform strategies and fulfill the requirements of section 76 (4) of the Public Finance Management Act of 1999. Table 1 indicates the objectives of procurement in South Africa as contained in the Constitution.

Table 1: Public Procurement Objectives in South Africa as Set Out in the Constitution

\begin{tabular}{|l|l|l|}
\hline Objective & $\begin{array}{l}\text { Procurement system to be fair, equitable, transparent, competitive and cost- } \\
\text { effective. }\end{array}$ & Section 217(1) \\
\hline Primary & $\begin{array}{l}\text { Procurement policy may provide for } \\
\text { (1) categories of preference in the allocation of contracts, and } \\
\text { (2) the protection or advancement of persons, or categories of persons, } \\
\text { disadvantaged by unfair discrimination. }\end{array}$ & Section 217(2) \\
\hline
\end{tabular}

Source: Bolton (2006:203); Watermeyer (2011:3)

There are also numerous legislative frameworks that guide procurement practices. Table 2 summarizes the Acts and their functions in procurement practices in South Africa.

Table 2: Primary Acts that Regulate Procurement

\begin{tabular}{|c|c|}
\hline Act & What it does in respect of procurement \\
\hline $\begin{array}{l}\text { Public Finance Management } \\
\text { Act } 1 \text { of } 1999\end{array}$ & $\begin{array}{l}\text { Establishes a regulatory framework for SCM, which includes procurement in national and } \\
\text { provincial departments and state-owned enterprises. }\end{array}$ \\
\hline $\begin{array}{l}\text { Promotion of Administrative } \\
\text { Justice Act } 3 \text { of } 2000\end{array}$ & $\begin{array}{l}\text { Establishes fair administrative procedures, permits those affected by unfair administrative } \\
\text { action to request reasons for such administrative action, and requires administrators to } \\
\text { respond to such requests. (Administrative actions are presumed to have been taken } \\
\text { without good cause where an administrator fails to respond within the prescribed period). } \\
\text { Provides for procedures for the judicial review of administrative actions and remedies in } \\
\text { proceedings for judicial review, including the prohibition of an administrator from acting in } \\
\text { a particular manner, setting aside the administrative action, correcting the defective } \\
\text { action and ordering the administrator to pay compensation. }\end{array}$ \\
\hline $\begin{array}{l}\text { The Promotion of } \\
\text { Equality and the } \\
\text { Prevention of Unfair } \\
\text { Discrimination Act } 4 \text { of } 2000\end{array}$ & $\begin{array}{l}\text { Prohibits the state or any person from discriminating unfairly against any person on the } \\
\text { grounds of race or gender through the denial of access to contractual opportunities for } \\
\text { rendering services, or by failing to take steps to reasonably accommodate the needs of } \\
\text { such persons. }\end{array}$ \\
\hline $\begin{array}{l}\text { Preferential Procurement } \\
\text { Policy Framework Act } 5 \text { of } \\
2000\end{array}$ & Establishes the manner in which preferential procurement policies are to be implemented. \\
\hline Construction Industry & Establishes the means by which the Board can promote and implement policies, \\
\hline
\end{tabular}




\begin{tabular}{|l|l|}
\hline $\begin{array}{l}\text { Development Board Act 38 } 2000 \\
\text { of }\end{array}$ & $\begin{array}{l}\text { programmes and projects, including those aimed at procurement reform, standardization } \\
\text { and uniformity in procurement documentation, practices and procedures within the } \\
\text { framework of the procurement policy of government, through the establishment of: } \\
\text { (1) a national register of contractors (and if required, consultants and suppliers) to manage } \\
\text { public sector procurement risk and facilitate public procurement; } \\
\text { (2) a register of projects above a particular financial value, with data relating to contracts } \\
\text { awarded and completed, and a best practice project assessment scheme; } \\
\text { (3) best practices which establish a code of conduct for the parties engaged in } \\
\text { construction procurement. }\end{array}$ \\
\hline $\begin{array}{l}\text { Broad-based Black } \\
\text { Act } 53 \text { of } 2003\end{array}$ & $\begin{array}{l}\text { Establishes a code of good practice to inform: } \\
\text { - the development of qualification criteria for the issuing of licences or concessions, the } \\
\text { sale of state-owned enterprises and for entering into partnerships with the private sector; } \\
\text { and } \\
\text {-the development and implementation of a preferential procurement policy. }\end{array}$ \\
\hline $\begin{array}{l}\text { Local government: } \\
\text { Municipal Finance } \\
\text { Management Act } 56 \text { of } 2003\end{array}$ & $\begin{array}{l}\text { Establishes a regulatory framework for supply chain management which includes } \\
\text { procurement in municipalities and municipal entities. }\end{array}$ \\
\hline $\begin{array}{l}\text { Prevention and } \\
\text { Combating of Corrupt } \\
\text { Activities, Act } 12 \text { of } 2004\end{array}$ & $\begin{array}{l}\text { Makes corruption and related activities an offence; establishes a Register in order to place } \\
\text { certain restrictions on persons and enterprises convicted of corrupt activities relating to } \\
\text { tenders and contracts; and places a duty on certain persons holding a position of authority } \\
\text { to report corrupt transactions. }\end{array}$ \\
\hline
\end{tabular}

Source: Adapted from Watermeyer (2011:3)

Table 2 above presents a snapshot of some of the important Acts of government in terms of public procurement in South Africa.

\section{TRENDS AND DEVELOPMENTS IN PUBLIC PROCUREMENT}

Since 1995, with the enactment of procurement reforms and the introduction of SCM as a procurement and socio economic tool, numerous trends and developments have evolved. In this article, some of these key trends and developments are discussed.

\subsection{Regulatory Framework for Supply Chain Management}

In 2003 , recognizing the need to further reform the procurement system and align it with international best practices, and also to improve financial management, the Cabinet approved the Supply Chain Management Policy. The Regulatory Framework for Supply Chain Management (2003) is applicable to all national and provincial departments, while the MFMA (2003) covers the supply chain management functions of local government authorities. These regulations aim to incorporate individual functions within an organization into the integrated supply chain process, considering the full chain of events from sourcing through to the use and disposal of the product. The regulations also empower the National Treasury to issue practice notes that address relevant supply chain management topics with a view to ensuring uniform minimum norms and standards within government.

The National Treasury published the first review of the supply chain management policy in 2015. This was the first major assessment of the system of buying goods and services by the public sector since 2004. In the review, the National Treasury acknowledged the challenges related to the implementation of the SCM policy. Among the major issues to be addressed, was the fact that SCM was often misunderstood and undervalued. Additionally, its strategic importance was not recognized and it was under-capacitated. The result of the assessment/review was the establishment of the chief procurement officer at the national Treasury (National Treasury, 2015).

\subsection{National Treasury Practice Notes and Circulars}

The National Treasury has played a pivotal role in the introduction of financial management reforms across government since 1994, and in local government since 1996. The cornerstone of the reform initiative has been implemented through the Municipal Finance Management Act 56 of 2003 (MFMA), and the Public Finance 
Management Act 1 of 1999 (PFMA). To fulfil this responsibility of SCM implementation in government, the National Treasury has developed a phased implementation strategy to provide financial and technical support to government. Since 2004, the National Treasury has been providing support to departments and municipal entities regarding the implementation of SCM. Because procurement is a policy tool for managing public procurement, whenever necessary, the National Treasury releases policies and regulations to enable the country to advance its economic agenda. These policies and regulations are produced in the form of practice notes for National Departments, and municipal circulars for Municipalities and its entities

\subsection{Preferential/Targeted Procurement}

Preferential procurement means that the public or private sector targets certain bidders, products, industrial sectors or areas, and therefore prefers them above others. The terms "preferential procurement" and "targeted procurement" are interrelated. They do not necessarily mean different things. The notion of preferential procurement is derived from the Preferential Procurement Policy Framework Act 5 of 2000 and its Regulations. This Act provides for the implementation of a policy and a system where bids (tenders) are not awarded purely on meeting specifications or having the lowest price, but on a prescribed points system were preference is given to Historically Disadvantaged Individuals (HDI's). Section 2(a) of the PPPFA stipulates that an organ of state must determine its preferential procurement policy and implement it within a prescribed framework. The regulations prescribed in 2001 under the act, allowed organs of state to also incorporate functionality criteria in the price component of the points system (Bolton, 2014:3). Regulation 19 of 2001, which allows for the incorporation of functionality criteria in the award stage of the procurement process, is ultra vires an enabling legislation in terms of the Procurement Act.

The new 2011 Procurement Regulations do not make reference to the attainment of "specific goals" as such. The award of preference points is tied to a supplier's certified Broad-Based Black Economic Empowerment (BBBEE) status in terms of the Broad-Based Black Economic Empowerment Act (BBBEEA). The higher the BBBEE rating of a supplier, the higher the number of preference points awarded. The supplier who scores the highest total number of points out of 100 (for price and preference in the form of BBBEE) is then generally awarded the contract. The 2011 Regulations provide for a situation where, if two or more bidders score an equal number of points in total, the contract must be awarded to the bidder who scored the most preference points for BBBEE (Bolton, 2014:4). The Preferential Procurement Regulations of 2011 stipulate guidelines for the implementation of the 80/20 and the 90/10 preference points systems respectively, as illustrated in Table 3 .

Table 3: Comparison of the $80 / 20$ and the 90/10 Preference Points Systems

\begin{tabular}{|l|c|}
\hline $\begin{array}{l}\text { 80/20 preference points system: section5(1-5) of the } \\
\text { preferential procurement regulations, 2011 }\end{array}$ & $\begin{array}{l}\text { 90/10 preference points system: section 6(1-5) of } \\
\text { the preferential procurement regulations, 2011 }\end{array}$ \\
\hline $\begin{array}{l}\text { Rand value equal to or above R30 000 and up to a } \\
\text { Rand value of R1 million }\end{array}$ & $\bullet \quad$ Rand Value above R1 million \\
\hline $\begin{array}{l}\text { A maximum of } 20 \text { points may be awarded to a } \\
\text { tenderer in respect of B-BBEE }\end{array}$ & $\bullet \quad \begin{array}{l}\text { A maximum of } 10 \text { points may be awarded to } \\
\text { a tenderer in respect of B-BBEE }\end{array}$ \\
\hline $\begin{array}{l}\text { The points scored by a tenderer in respect of the } \\
\text { goals contemplated above must be added to the } \\
\text { points scored for price }\end{array}$ & $\begin{array}{l}\text { The points scored by a tenderer in respect of } \\
\text { the goals contemplated above must be } \\
\text { added to the points scored for price }\end{array}$ \\
\hline $\begin{array}{l}\text { Only the tenderer who scores the highest } \\
\text { number of points may be selected }\end{array}$ & $\begin{array}{l}\text { Only the tenderer who scores the highest } \\
\text { number of points may be selected }\end{array}$ \\
\hline
\end{tabular}

Source: Preferential Procurement Policy Framework Act 5 of 2000; Preferential Procurement Regulations (2011:6).

Since June 2011 HDI points are now allocated based on the seven pillars of the B-BBEE scorecard. Thus the constitutional provision for public procurement to be used as a policy tool has already been implemented to a large degree in practice. The PPPF Act entrenches the South African government's commitment to economic growth by implementing measures to support industry generally, and to advance the development of both SMMEs and HDIs specifically. Public procurement thus provides a continuous means through which the South African government, at all levels, strategically advances the social and economic objectives and priorities. 


\subsection{Broad-Based Black Economic Empowerment (B-BBEE) and Verification Agencies}

The B-BBEE is an important Act which provides various scores based on weighting, and is related to the classification of bidders. B-BBEE is defined as an integrated and coherent socio-economic process that contributes directly towards economic transformation in South Africa by significantly increasing the number of black people that manage, own and control the country's economy, and by significantly decreasing income inequalities (Balshaw \& Goldberg, 2008:75). In the B-BBEE Act, Broad-Based BEE is further defined as "the economic empowerment of all black people, as well as female workers, youth, people with disabilities and people living in rural areas, through diverse but integrated socio-economic strategies" that include, but are not limited to the following (Balshaw \& Goldberg, 2008:75):

- "increasing the number of black people that manage, own or control enterprises and productive assets;

- facilitating ownership and management of enterprises and productive assets by communities, workers, cooperatives and other collective enterprises;

- human resources and skills development;

- $\quad$ achieving equitable representation at all occupational categories and levels within the workforce;

- Preferential procurement; and

- Investment in enterprises that are owned or managed by black people".

Both these definitions refer to an integrated approach, which is inclusive of all economic factors that contribute towards meaningful economic growth. The BEE Codes of Good Practice were gazetted on 9 February 2007 under section 9(1) of the B-BBEE Act of 2003.

According to the revised PPPF Act of 2011, BEE Status Level Certificates were to be implemented. Thus, BEE was no longer calculated in terms of the bidding process. Bidders were required to submit original and valid BBBEE Status Level Verification Certificates or certified copies thereof, together with their bids, to substantiate their B-BBEE rating claims. Bidders who did not submit B-BBEE Status Level Verification Certificates were considered to be non-compliant contributors to B-BBEE, and would not qualify for preference points in terms of BBBEE. However, such bidders were not disqualified from the bidding process. Verification agencies were accredited for the evaluation of the BEE composition of companies. Examples of verification agencies are SANAS and IRBA. Accounting officers accredited by SANAS and the CCA were also engaged in the verification process (issuing EMEs and B-BBEE Status Level Certificates). Companies are classified as EMEs based on their financial status (PPR, 2011:6). Table 4 presents the elements and weightings of the generic B-BBEE scorecard and code series references.

Table 4: Elements and Weightings of the Generic B-BBEE Scorecard

\begin{tabular}{|c|c|c|c|}
\hline \multicolumn{2}{|c|}{ B-BBEE PILLAR } & WEIGHTING & REGULATORY OBJECTIVE \\
\hline \multirow{2}{*}{ 七 } & Ownership & $20 \%$ & $\begin{array}{l}\text { Encourages the sharing of ownership which will result in voting rights for } \\
\text { black people in general and black women in particular }\end{array}$ \\
\hline & Management & $10 \%$ & $\begin{array}{l}\text { Encourages senior black decision-making at executive board and senior top } \\
\text { management levels }\end{array}$ \\
\hline \multirow{2}{*}{ 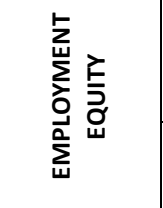 } & Employment equity & $15 \%$ & $\begin{array}{l}\text { Encourages companies to identify and recruit black people in professional, } \\
\text { middle and lower management positions }\end{array}$ \\
\hline & Skills development & $15 \%$ & $\begin{array}{l}\text { Encourages companies to develop black talent through spending on skills } \\
\text { development and learnerships }\end{array}$ \\
\hline 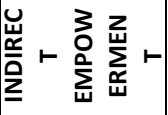 & $\begin{array}{l}\text { Preferential } \\
\text { procurement }\end{array}$ & $20 \%$ & $\begin{array}{l}\text { Encourages the development or expansion of black small, and medium } \\
\text { enterprises }\end{array}$ \\
\hline
\end{tabular}




\begin{tabular}{|l|l|l|l|}
\hline & $\begin{array}{l}\text { Enterprise } \\
\text { development }\end{array}$ & $\begin{array}{c}\text { Measures the extent to which enterprises procure from BEE-compliant } \\
\text { companies. Encourages spending on small and micro enterprises as well as } \\
\text { on black-owned companies }\end{array}$ \\
\hline \multirow{2}{*}{} & Socio-economic & $\mathbf{5 \%}$ & $\begin{array}{r}\text { Encourages initiatives intended to directly provide black people with a } \\
\text { means of generating income for themselves }\end{array}$ \\
\hline
\end{tabular}

Source: DTI (2013).

The generic scorecard comprises seven elements which are measured as a total score out of 100 . The scorecard assists in explaining how each indicator is measured. A distinction can be made between an exempted microenterprise (EME) with a total revenue of R5 million or less, a qualifying small enterprise (QSE) with total revenue of between R5 million and R35 million, and a start-up enterprise, which is measured as an EME for the first year of formation or incorporation. An EME is deemed to have a BBBEE status of level 4 or level 5 in instances where more than $50 \%$ is owned by black people. A QSE must select any four of the seven elements on the scorecard for measurement to determine its compliance (Kruger (2011:210-211). Measurement of an enterprise as a 'contributor' in terms of the generic scorecard, determines its B-BBEE status on the basis of the qualification in terms of points scored, including its BBBEE recognition level as shown in Table 5. Table 5 presents the new BBBEE status, qualification and recognition level.

Table 5: B-BBEE Status, Qualification and Recognition Level

\begin{tabular}{|l|l|c|}
\hline BBBEE Status & Qualification & $\begin{array}{c}\text { BBBEE recognition level } \\
\text { (percentage) }\end{array}$ \\
\hline Level ONE contributor & $\geq 100$ points on the Generic Scoreboard & 135 \\
\hline Level TWO contributor & $\geq 85$ but $<100$ on the Generic Scorecard & 125 \\
\hline Level THREE contributor & $\geq 75$ but $<85$ on the Generic Scorecard & 115 \\
\hline Level FOUR contributor & $\geq 65$ but $<75$ on the Generic Scorecard & 100 \\
\hline Level FIVE contributor & $\geq 55$ but $<65$ on the Generic Scorecard & 80 \\
\hline Level SIX contributor & $\geq 45$ but $<55$ on the Generic Scorecard & 60 \\
\hline Level SEVEN contributor & $\geq 40$ but $<45$ on the Generic Scorecard & 50 \\
\hline Level EIGHT contributor & $\geq 30$ but $<40$ on the Generic Scorecard & 10 \\
\hline NON-COMPLIANT contributor & $<30$ on the Generic Scorecard & 0 \\
\hline
\end{tabular}

Source: DTI (2013)

\subsection{Electronic Tax Clearance System}

In 2014, an electronic tax compliance status (TCS) was developed and came into effect on 1 November 2014 (NT Instruction 3, 2014). The objective of the system was to reduce fraud and ensure that the SCM system is not abused. According to the regulation and with effect from 1 April 2015, SARS would no longer issue paperbased tax clearance certificates. According to the National Treasury instruction note 3 of 2014/2015, dated 15 July 2014, persons or institutions conducting business with the state are no longer required to obtain a hard copy of an original and valid tax clearance certificate. Rather, the tax compliance status of bidders should be checked through the tax compliance status (TCS) system (NT, 2014a).

The database would interface with the South African Revenue Services, the Companies and Intellectual Property Commission and the payroll system, and would electronically verify a supplier's tax and black employment equity status. The system would also be able to identify a public sector official who was trying to do business with the state. All tenders would be advertised on the e-tender portal, and all tender documents would be open to the public. Accordingly, "tender advertisements in newspapers and the Government Gazette will be phased out" (Mail \& Guardian, 2015). 


\subsection{Minimum Threshold for Local Content Production}

The Preferential Procurement Regulations (2011) made provision for the department of Trade and Industry (DTI) to designate sectors in line with the National and industrial policies for local production. In this regard, bids are advertised with specific bidding conditions. Regarding local content production, bids in respect of services, works or goods that have been designated for local production and content, must contain a specific bidding condition that only locally produced goods, services or works, or locally manufactured goods with a stipulated minimum threshold for local production and content, will be considered. The Local Procurement Accord (2011) is a political agreement that aims to achieve a 75 per cent local production of goods and services by 2020. Significantly, the Accord clearly links public procurement to larger issues faced by the South African economy and society. Section 9 of the PPPFA Regulations was revised in December 2011 to include this new and ambitious focus on local production and content. The new regulations provide for the designation of specific sectors, subsectors and products that all public entities (national, provincial, municipal and SOEs) are required to procure locally.

The 2011 revisions to the PPPFA Regulations empowered the DTI to designate industries, sectors and subsectors for local production at a specified level of local content. The DTI has selected seven sectors for these minimum local content thresholds, which are: rolling stock, power pylons, bus bodies, canned/processed vegetables, textiles/clothing/ leather/footwear, setup boxes for digital TV migration, and pharmaceuticals. These sectors, along with the prescribed minimum thresholds for local content, are shown in Table 6 below. In other non-designated sectors, state entities can include, as a specific tendering condition, a threshold for the minimum level of local content (DTI, 2013). Sectors planned for further consideration by the DTI include electrical and telecom cables, solar water heaters, schools, and office furniture (DTI, 2012). Table 6 shows an example of the minimum thresholds for local content as a percentage.

Table 6: Minimum Threshold for Local Content

\begin{tabular}{|l|c|}
\hline Industry/sector/sub-sector & $\begin{array}{c}\text { Minimum threshold } \\
\text { for local content }\end{array}$ \\
\hline Buses (bus body) & $8 \%$ \\
\hline Textiles, clothing, leather and footwear & $100 \%$ \\
\hline Power pylons & $100 \%$ \\
\hline Canned / processed vegetables & $80 \%$ \\
\hline Rolling stock & $65 \%$ \\
\hline Pharmaceutical products (oral solid dosage tender) & $73 \%$ \\
\hline Set-top boxes for TV digital migration & $30 \%$ \\
\hline Furniture & \\
$\bullet \quad$ Office Furniture & $85 \%$ \\
$\bullet \quad$ Base and Mattress & $100 \%$ \\
\hline Power and telecom cables & $90 \%$ \\
\hline Solar Water Heaters (collectors and storage tanks/geysers) & $90 \%$ \\
\hline
\end{tabular}

Source: DTI (2013)

\subsection{The role of "Functionality" in the Procurement Process}

Functionality can be defined as "the measurement according to predetermined norms, as set out in the tender documents, of a service or commodity that is designed to be practical and useful, working or operating, taking into account, among other factors, the quality, reliability, viability and durability of a service and the technical capacity and ability of a tenderer". In December 2011, the PPPFA was amended by the National Treasury, along with the Department of Trade and Industry (DTI) and the Economic Development Department (EDD). The main objectives of the amendments were to support economic development, to reduce fraud and corruption, and to ensure transparency in the procurement process (Porteous \& Naudé, 2012). Between 2004 and 2010, functionality criteria formed part of the award stage of the procurement process and played a decisive role in 
determining the winning bidder. Under the 2001 Procurement Regulations, which were in force from around 2001 to the end of 2011, functionality could, for the most part, be incorporated into the award stage of the procurement process. In determining a winning bidder, points could be awarded, not only for price and certain preference criteria, but also for functionality criteria. More specifically, functionality was an award criterion along with price.

Under the 2011 Procurement Regulations, functionality criteria have been given a very specific role. An organ of state must determine whether functionality is relevant to the particular procurement, and if so, it must provide for it during the qualification stage of the process. When an institution invites a bid that will also be evaluated on the basis of functionality as a criterion, the following aspects should be taking into consideration:

- evaluation criteria for measuring functionality

- weight of each criterion

- applicable value

- minimum qualifying score for functionality

Bidders must be required to meet certain minimum scores for functionality, and only those bidders who meet such scores will then qualify for further evaluation on the basis of price and preference during the award stage (Bolton, 2014:1). The evaluation criteria for functionality must be specified in the bid documents. The criteria may include relevant experience, qualifications of key personnel, transfer of knowledge, etc. The weight to be allocated to each criterion must not be generic, but determined with reference to each bid on a case-by-case basis. The scoring for each criterion should also be objective. For example, the following values may be used: 1 may mean poor, 2 is average, 3 is good, 4 is very good, and 5 may mean excellent. The minimum score for functionality to qualify a bidder for further evaluation must also not be generic, but must be determined separately with reference to each bid. The minimum qualifying score must also not to be so low that quality is jeopardized. At the same time, it must not be too high to ensure fair treatment of bidders (Bolton, 2014:18).

In the event that two or more bids have scored equal total points, the successful bid will be the one scoring the highest number of preference points for B-BBEE. However, when functionality is part of the evaluation process and two or more bids have scored equal points, including equal preference points for B-BBEE, the successful bid will be the one scoring the highest score for functionality. Should two or more bids be equal in all respects, the award shall be decided by the drawing of lots.

\subsection{Centralized Supplier Database}

In April 2015 the treasury launched a central supplier database and a central e-tender portal in a bid to fight corruption and make government procurement more efficient and cost-effective. In 2013-2014, the public sector spent some R500-billion on goods, services and construction, of which at least R30-billion was lost due to corruption. The overhaul of the government's procurement processes and policies began with the establishment of the office of the Chief Procurement Officer at the National Treasury in 2013. The central supply database is meant to oversee the way in which government does business with the private sector. Suppliers will be required to register once when they do business with the state. The objective is to reduce the administrative burden for business, especially small and medium-sized enterprises. This intervention will also reduce the administrative burden for SCM practitioners (Mail \& Guardian, 2015).

\subsection{Integration of Government Procurement Systems}

There are currently 36 different government SCM systems, which are generally poorly integrated and nonautomated. Internal controls are diluted by not being applied consistently and this contributes to the high levels of non-compliance reported on by the auditor general. The treasury plans to replace all these systems with a single system, the integrated financial management system (IFMS), and the central supplier database will fall under it. This will make data mining possible. It will assist the government to identify trends, calculate costs accurately and improve the planning and costing procedures when compiling the budgets of departments, municipalities and parastatals (Mail \& Guardian, 2015). 


\subsection{Contract Centralization of Certain Government Services}

The government intends to centralize contracts for banking services, computers, information communication technology (ICT) services and infrastructure, consulting services, security services, air travel and accommodation, school textbooks and stationery, healthcare equipment and leased buildings. Centralized contracting is an "important instrument" which will enable the government at all levels to buy goods and services from a central list of approved suppliers who have been vetted for cost and quality. The South African government has 37 central contracts covering 8000 line items worth a total of R16-billion. Indications are that the value of goods and services procured using central contracts will be increased significantly with the new line items. The government spends R12-billion on consulting services, R10-billion on ICT, R5-billion on air travel and accommodation, and R3.5-billion on security services. These four categories add up to more than R30billion, almost double the value of all centralized contracts. According to the review, the list of nationally negotiated contracts will be expanded over the next three years and will save the government "significant sums" (Mail \& Guardian, 2015).

\subsection{Establishment of the Office of the Chief Procurement Officer}

The Office of the Chief Procurement Officer (OCPO) was established in 2013. The primary purpose was to modernize and oversee the South African public sector SCM system, to ensure that the procurement of goods, services and construction works is fair, equitable, transparent, competitive and cost effective in line with the Constitution and all relevant legislation. The OCPO is not directly involved in procurement, but leads and manages procurement reform, maintains the procurement system and oversees the way in which government does business with the private sector. In line with the PFMA and the MFMA, the accounting officers and accounting authorities of departments and entities are responsible for all day-to-day SCM activities. Their responsibilities will include developing their own SCM policies and management systems, and provide staff training and development in line with the national supply chain framework. They will also be required to adhere to national supply chain norms and standards of reporting and compliance (SCM Review, 2015:6).

From the discussions above, it is evident that public procurement in South Africa has undergone dramatic transformation. The transformation was enacted due to fragmented processes and is currently evolving in the quest for better services.

\section{CONCLUSION}

Procurement in the South African public sector is a key mechanism enabling government to implement socioeconomic objectives. The article explored trends and developments in public procurement in South Africa. This conceptual review indicates that procurement transformation continues to evolve in South Africa under the SCM umbrella. Over the years, SCM has been undervalued and misunderstood. Public procurement continues to face challenges and has undergone various transformations, such as changes in the regulatory framework for SCM, the continuous support through treasury notes and municipal circulars, the new role of functionality in the procurement process, the establishment of verification agencies, the employment of electronic tax systems, the establishment of minimum thresholds for local content production, the use of a centralized procurement database, the integration of government procurement systems, as well as contract centralization of certain government services.

These transformations are driven by the National Treasury, which continues to provide support services in all spheres of government in an effort to improve government procurement and to ensure value for money. It is important that procurement practitioners and academic institutions take centre stage in the enhancement of procurement practices in the country. This includes developing more sophisticated academic curricula to build capacity for the public sector, leverage private sector procurement practices relative to government, develop an ethical culture in terms of the application of procurement practices, as well as add value to procurement as a socio-economic tool in the country. This will promote stronger leadership and ensure more effective government procurement practices. It is hoped that the country will see more transformation and socioeconomic development through the leadership of the CPO. Additionally, sound supplier relationship management systems should be established between government entities and their strategic suppliers. 
Traditionally, supplier relationships in the public sector has often been misinterpreted, and this has led to many instances of corruption.

\section{REFERENCES}

Ambe, I.M. 2009, An exploration of supply chain management practices in the central district municipality. Educational Research and Review 4(9):427-435.

Bolton, P. 2006, "Government procurement as a policy tool in South Africa", Journal of Public Procurement 6(3):193-217.

Bolton, P. 2009, "Government procurement and policy promotion in South Africa", in Procurement from developing countries and economies in transition. UNOPS, 2009.

Bolton, W. 2006, "An analysis of the criteria used to evaluate and award public tenders", Speculum Juris 2014(1).

Business Day, 2011, "Irregular state expenditure jumps 62\%", Smart Procurement. www.smartprocurement.co.za/achives/irregular state enpenditure 62.p (accessed on 10 February 2012).

Cane, P. 2004, "Administrative law", 4th edition. London: Oxford University Press.

DTI. 2012, “Industrial Procurement and Designation of the Sectors", http://www.thedti.gov.za/parliament/ industrial_procurement.pdfDesign (accessed on 15 Dec 2015).

DTI. 2013, “Industrial Policy Action Plan”, http://www.thedti.gov.za/news2013/ipap_2013-2016.pdf (accessed on 12 Jan 2016).

Eyaa, S. \& Oluka, P.N. 2011, "Explaining noncompliance in public procurement in Uganda”, International Journal of Business and Social Science 2(11), June: 35-44.

Gurría, A. 2016, "Public procurement for sustainable and inclusive growth: Enabling reform through evidence and peer reviews", OECD; http://www.oecd.org/gov/ethics/PublicProcurementRev9.pdf (accessed on 21 April 2016).

Kashap, S. 2004, "Public procurement as a social, economic and political policy", International Public Procurement Conference Proceedings, vol. 3:133-147.

Krüger, L.P. 2011, "The impact of black economic empowerment (BEE) on South African businesses: Focusing on ten dimensions of business performance", Southern African Business Review 15(3):207-233.

Mail \& Guardian. 2015, "Government supplier database: A blow to corruption", http://mg.co.za/article/2015-03-05-govt-supplierdatabase-a-blow-to-corruption (accessed on 13 April 2015)

Matthee, C.A. 2006, "The potential of internal audit to enhance supply chain management outcomes", Master's dissertation, University of Stellenbosch, Stellenbosch

McCrudden, C. 2004, "Using public procurement to achieve social outcomes", Natural Resources Forum:257-267.

Mnguni, N. 2012, "To investigate and evaluate the implementation of the supply chain management in service delivery with specific focus on procurement processes of goods and service in the head office of the Eastern Cape Department of Health", Unpublished Maters Dissertation. Nelson Mandela Metropolitan University: Faculty of Business and Economic Sciences.

Munzhedzi, P. H. 2016, "South African public sector procurement and corruption: Inseparable twins", Journal of Transport and Supply Chain Management. <Vol, ed. \& page numbers?>

NT, vide South Africa. National Treasury.

OECD. 2007, "SIGMA support for improvement in governance and management", http://sigmaweb.org (accessed on 20 January 2012 )

OECD. 2015, "Organisation for Economic Co-operation and Development fighting corruption in the public sector: Public procurement", http://www.oecd.org/gov/ethics/integrityinpublicprocurement.htm (accessed on 11 Feb 2016).

Porteous, E. \& Naudé, F. 2012, “Public sector procurement: The new rules”, http://www.apmp.org.za/public ftp/ PPPFA\%20presentation\%20for\%20web.pdf (accessed on 10 Nov 2015).

South Africa. National Treasury. 2003, "Policy strategy to guide uniformity in procurement reforms processes in government", Pretoria, National Trewasury.

South Africa. National Treasury. 2005, "Supply chain management: A guide for accounting officers and municipal entities", Pretoria, National Treasury.

South Africa. National Treasury, 2015, “2015 Public sector supply chain management review”, Pretoria. National Treasury, 2015. 
Turley, L. and Perera, O. 2014, "Implementing sustainable public procurement in South Africa: Where to start?", The International Institute for Sustainable Development.

Uyarra, E. \& Flanagan, K. 2009, "Understanding the innovation impacts of public procurement", Manchester Business School working paper, no. 574. http://www.mbs.ac.uk/research/workingpapers/(accessed on 19 January 2012)

Watermeyer, R.B. 2011, "Regulating public procurement in Southern Africa through international and national standards", Public Procurement Regulation in Africa Conference, 25 October, Stellenbosch. 